\title{
A kognitív tudományok hatása a kartográfiára
}

\author{
SZIGETI-PAP Csaba
}

DOI: $10.30921 / G K .73 .2021 .5 .4$

Absztrakt: A kognitiv kartográfia a térképészet azon ága, amely a térképolvasás, értelmezés és tájékozódás kognitív folyamatait kutatja. A célja a térkép információtartamának és információátadásának a maximalizálása, amellyel a kartográfiai kommunikációt hatékonyabbá lehet tenni. A kartográfiai kommunikáció modelljének az alapja a közlő (térképszerkesztô) és befogadó (térképolvasó) közti ismeretátadás, amely egy médiumon (térkép) keresztül történik. Ugyanakkor jelentốs szerepe van a modellben a szubjektivitásnak, mivel a térképész másként értelmezi a közölt információt, mint a befogadó. Emellett a térképolvasók közt is különbségek léphetnek fel, kognitív képességeiktôl függóen. A helytelen ábrázolásmód nehezítheti a térképi ismeretek átadását, kognitív terhelés léphet fel. Mindezekból adódik, hogy a térképész feladata olyan ábrázolásmód alkalmazása, amely a térképolvasók számára az ismeretet a leghatékonyabb módon képes átadni, a kognitív terhelés minimalizálásával.

Abstract: Cognitive cartography studies the cognitive processes during map reading and navigation. Its goal is to maximize the maps' information content and transfer, thus making the cartographic communication more efficient. The base of the cartographic communication is the knowledge-transfer between the sender (cartographer) and the receiver (map reader), which happens through a medium (the map). Still, subjectivity plays a great role in the model, because the cartographer interprets reality in a different way than the receiver. Improper visualization makes the transfer of information difficult, which creates cognitive load. In this respect, it is the cartographers' role to use such methods of visualization that can transfer knowledge to the map readers in the most efficient way, while minimalizing the cognitive load.

Kulcsszavak: kognitív kartográfia, kartográfiai kommunikáció, kognitív terhelés elmélet Keywords: cognitive cartography, cartographic communication, cognitive load theory

\section{Bevezetés}

Térképszerkesztés során az egyik legjelentôsebb probléma a megfelelő jelkulcs kialakítása. Ennek segítségével maximalizálni lehet a térképek információtartamát, így a térképolvasó több ismerethez juthat (Board 1978). A térképészek a XX. századig kizárólag intuitív módon oldhatták meg ezt a problémát (Montello 2002, Bunch-Lloyd 2006). A kognitív tudományok megjelenésével azonban betekintést lehetett nyerni a térképolvasás mentális folyamataiba is. A kognitív tudományok a XX. század közepén jelentek meg. Ezek olyan interdiszciplináris tudományok, amelyek célja az elme és az intelligencia, valamint azok folyamatainak vizsgálata. Többek között magába foglalja a pszichológia, filozófia, idegtudomány, nyelvészet, antropológia és a mesterséges intelligencia kutatásának egyes ágait is (Thagard 2014).

A térképolvasás hatékonyságát több tényezô is befolyásolja. Wakabayashi (2013) bemutatta, hogy a kis méretarányú térképek (ország-, kontinens-, világtérképek) olvasásakor a földrajzi ismeretek, a nagy méretarányú térképek (pl. topográfiai térképek) értelmezésekor a kognitív képességek játszanak jelentôsebb szerepet. Ezen kognitív képességek közé tartoznak az olyan téri képességek, mint a térérzékelés (környezó objektumok elhelyezkedésének értelmezése), mentális forgatás (2 és 3D-s objektumok fejben történô forgatása), térbeli vizualizáció (térbeli információ értelmezése, manipulálása) (Donnon et al. 2005).

A memóriának szintén jelentôs szerepe van a térképolvasásban. Befolyásolja a domborzati elemek felismerését és értelmezését (Guzmán et al. 2008), a térképi információ feldolgozását (Ooms et al. 2012), valamint a tájékozódást is (Bianchini et al. 2013). A térképolvasási kutatásokban egyre jelentősebb szerepet játszik a kognitívterhelés-elmélet (cognitive load theory - CLT) (pl. Gerber 1981, Ooms et al. 2013). Az elmélet a hosszú távú memória és a munkamemória kapcsolatát fejti ki, és célja a tanulás, megismerés folyamatának hatékonyabbá tétele (Bunch-Lloyd 2006). Az elmélet jól beilleszthetố a kognitív kartográfiai kutatásokba is.

A térképolvasó neme szintén képes befolyásolni a térképolvasást (Albert et al. 2016, Lawton 1994). Ugyanakkor ez leginkább a téri-tájékozódási feladatoknál jelentős, a térképi jeleket mindkét nem hasonló módon képes értelmezni (Gilhooly et al. 1988, Montello et al. 1999).

További befolyásoló tényezô a térképolvasó származása. Ito és Sano (2011) bemutatták, hogy jelentôs különbségek vannak a japánok és az észak-amerikaiak térképhasználati és tájékozódási szokásaiban. Meglátásuk szerint több tényezố is hatással volt az eredményekre, például az eltérô térképhasználói kultúra és a földrajzoktatás különbözôsége. Hasonló eredményre jutottak Albert és társai (2016), ahol több ország egyetemi hallgatóinak térképolvasási képességeit vizsgálták.

\section{A kognitív kartográfia kialakulása}

A kognitív kartográfia az elméleti térképészet azon ága, amely a kognitív pszichológia kutatási módszerei és elméletei segítségével vizsgálja a térképhasználatot és térképértelmezést. Pápay, Klinghammer és Török (1995) megkülönböztetik a kartográfiai modellezést és az elméleti 
kartográfiát. Míg az előbbi a gyakorlati kartográfiát és a kartográfiai ábrázolásformák alkalmazását foglalja magába, addig az utóbbi a térképkészítés és térképhasználat elméleti vonatkozásaival foglalkozik (1.ábra).

Az elméleti kartográfia fejlődése már az ókorban megkezdôdött, a megszerzett tudás viszont a középkorban egy idôre feledésbe merült. A kartográfia tényleges tudományággá válása a XIX. században történt (Pápay et al. 1995). A kognitív kartográfiai kutatások kialakulását Montello (2002) foglalja össze, megjelenésüket pedig a XX. század második felére datálja. Négy tényezôt sorol fel, amelyek megalapozták a kartográfia ezen ágának kialakulását.

Az elsô mozgatórugója a katonai topográfiai térképezés volt. Az új haditechnológiáknak köszönhetôen a XVIII-XIX. században megnôtt az igény a mérhetô domborzatábrázolási módszerek alkalmazására (Taylor 1985). A korábbi, múvészi ábrázolásmódokat felváltotta a lejtôcsíkozás, amely a lejtôk meredekségét ábrázolta. Késóbb, a mérési technológia fejlôdésével a szintvonalas domborzatábrázolás vette át a helyét (pl. Zentai 2018). Ez a folyamat a korábbi múvészethez közeli ábrázolási módokat tudományos alapokra helyezte.

A második tényezô, a pszichológia tudománya szintén a XIX. században fejlôdött ki. Wilhelm Wundt 1879-ben alapította meg Lipcsében pszichológiai laboratóriumát. Wundt több társával együtt a pszichofizika területén végzett kutatásokat. Ez a pszichológiának egy olyan ága, amely a fizikai (testi) ingerek pszichikai kapcsolatát vizsgálja. (Hergenhahn-Henley 2013).

Jelentôs szerepe volt továbbá a kognitív kartográfiai kutatások kialakulásában a tematikus térképeknek, hiszen a modern empirikus térképszerkesztési kutatások a tematikus térképek jelábrázolásaival kezdôdtek (Board 1981). Habár már a XVII. században megjelentek a tematikus térképek, a valódi fejlôdés mégis a XIX. században indult meg. A természettudományok fejlôdése megkövetelte az

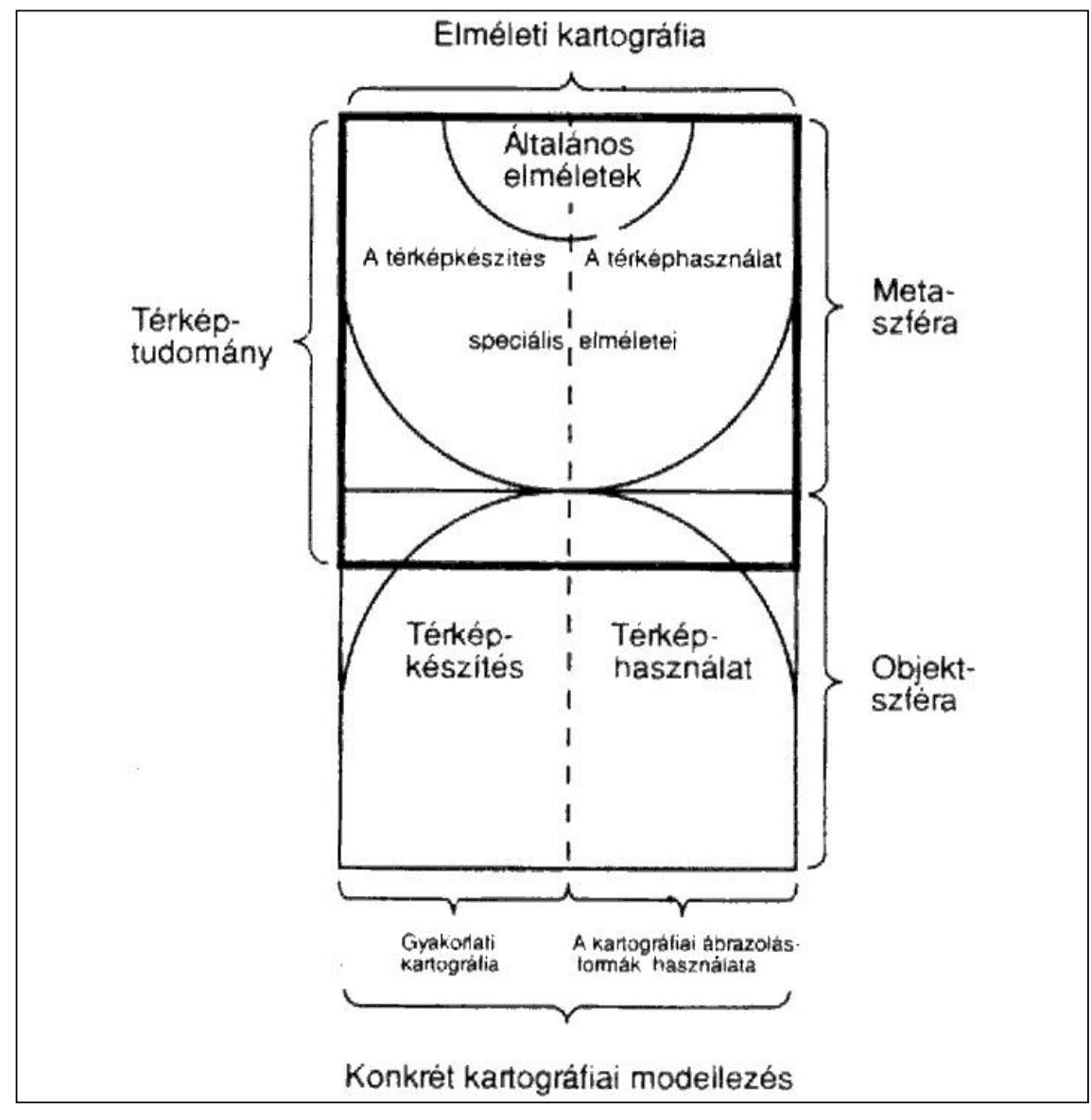

1. ábra. A kartográfia általános szerkezete (Pápay et al. 1995) adatok vizualizációját, ennek érdekében pedig újfajta ábrázolásmódokat hoztak létre (pl. Humboldt izotermatérképe) (Thrower 2008).

A negyedik meghatározó tényezô Montello szerint a múvészet volt. Az impresszionizmus, valamint a fotográfia XIX. századi megjelenése új megvilágításba helyezte a képek vizuális és érzelmi megjelenését, amely a térképszerkesztésre is hatással volt.

Max Eckert az 1921-ben és 1925-ben kiadott kétkötetes, Kartenwissenchaft (Térképtudomány) címú könyvében kifejti az elméleti és gyakorlati kartográfia kapcsolatát. Ír a pszichológia és a térképészet kapcsolatáról, és megemlíti, hogy pszichológiai kutatások a kartográfiában is alkalmazhatóak lehetnének. Ennek ellenére ô maga nem végzett el egy ilyen jellegú kutatást sem (Pápay et al. 1995, Montello 2002).

Megjelentek emellett a térképoktatással kapcsolatos kutatások is. Ezek jelentôsége, hogy már szisztematikus adatgyújtési módszereket alkalmaztak (pl. kérdôívezés) (Montello 2002). Ilyen kutatást mutat be például Gulliver 1908-ban megjelent cikke, amelyben az iskolai térképek tájolásának a gyermekek földrajzi ismereteire való hatását vizsgálta. Emellett kutatásokat végeztek adatvizualizációval kapcsolatban, például diagramok (Eells 1926), vagy geometriai jelek értelmezhetôségérôl (Croxton 1932).

1952-ben megjelent Robinson The Look of Maps: An Examination of Cartographic Design címú könyve, mely Montello (2002) szerint jelentôs hatással volt a kognitív kartográfiára és a térképtervezésre egyaránt. Robinson a könyvében Eckert gondolatmenetét követte, tovább fejtegette a szisztematikus mérések és adatgyújtések fontosságát.

Montello (2002) továbbá bemutatta, hogy a XX. század második felében egyre többen kezdték el vizsgálni a tematikus térképek ábrázolásmódjainak értelmezhetôségét, azok hatékonyságának növelése érdekében. Több kutatás (pl. Flannery 1971, Crawford 1971, Chang 1977) foglalkozott a térképi jelek méreteinek értékarányos módosításával. 
Emellett foglalkoztak a betútípusok (Shortridge 1979) és a színek megválasztásával (Olson 1975) is.

A tematikus térképek mellett a topográfiai (tehát a nagyobb méretarányú) térképek tervezésével kapcsolatban is végeztek kutatásokat, elsôsorban a domborzatábrázolást (szintvonalakat és domborzatárnyékolást) illetốen (pl. Hsu-Robinson 1970, Eley 1987, Eley 1992).

Az 1970-es és 1980-as évek folyamán több kutató is megpróbálta elkészíteni a kartográfiai kommunikáció modelljét, amely során a térképszerkesztô (közlô) a térképolvasónak (befogadó) a térképen keresztül (csatorna) adja át az információt. Az egyik legismertebb ezek közül Koláčný (1969) munkája, amely a kartográfiai kommunikáció alapjait fektette le. Freitag (1971) és Hake (1973) megfogalmazták a jelek, a szimbólumok és a nyelv szerepét a kartográfiai kommunikációban. Board (1981) a kartográfiai kommunikáció modelljét az információelmélettel kötötte össze.

A gyakorlati térképészetben többen félreértelmezték a kartográfiai kommunikációs modellt: sokan úgy vélték, a térkép célja csupán egy bizonyos üzenet átadása, és akkor jó egy térkép, ha ezt az üzenetet átadja. Ezt erôsítette az a tény is, hogy a kognitív kartográfiai kutatások eredményei nem alakítottak ki egy egységes képet: a legtöbb esetben a térképek értelmezésének olyan kis szeleteit vizsgálták, amelyek a gyakorlati kartográfiában nem nyújtottak konkrét segítséget. Petchenik (1977) kifejtette, hogy az eddigi kísérletek az alacsony szintû́ térképolvasási feladatokkal foglalkoztak (pl. térképi elemek észrevétele, méret meghatározása). Ehelyett olyan magasabb szintú feladatokat kellene vizsgálni, mint következtetések levonása a térképrôl, amely nem csak az egyes jeleket vizsgálja, hanem a térképi elemek kapcsolatait is.

Montello (2002) megemlíti a GIS megjelenését, amely háttérbe szorította a kognitív kartográfiai kutatásokat, mivel a fiatal nemzedék inkább ebben az irányban kezdett el kutatni. Ugyanakkor a számítógépes kartográfia megjelenése elősegítette a magas szintû kognitív feladatok vizsgálatát (pl. Slocum et al. 2001). Emellett a számítógépes kartográfia jelentôsen megkönnyíti a teszttérképek elkészítését, az adatgyújtést és adatfeldolgozást a kognitív kartográfiai kutatások számára.

Magyarországon is több kutatás foglalkozott a kognitív kartográfia és a térképértelmezés megismerésével. Pôdör (2002) horgásztérképen felhasználói tesztek segítségével vizsgálta, hogy milyen pontszerú jelekkel lehet leghatékonyabban információt átadni a térképolvasóknak. Bérces és Török (2014) a térképolvasás folyamatát szemmozgáskövetô kísérletekkel vizsgálta. Kutatásaik során elsôsorban tér-idő vonatkozású adatok tematikus vizualizációjával foglalkoztak. Török és társai 2018-ban a szemmozgáskövetés és a virtuális valóság segítségével további eredményeket értek el a térképolvasás és a városi tájékozódás területén. Az Eötvös Loránd Tudományegyetemen múködô Kísérleti Térképészeti Kutatócsoport (ktk.elte.hu) 2016 óta végez térképolvasással kapcsolatos online kutatásokat: nemzetközi vizsgálatban mérték egyetemisták térképolvasási képességeit (Albert et al. 2016), dinamikus jelkulcsú térképeket terveztek eltérô képességú térképolvasóknak (Albert et al. 2017, Szigeti et al. 2017), illetve nemzetközi kutatásban vizsgálták a vetületek hatását a térképolvasásra (Kerkovits-Szigeti 2018).

\section{A kartográfiai \\ kommunikáció modellezése}

Papp-Váry (2012) kifejtette, hogy a kartográfiai kommunikáció kutatását a tematikus térképek tették szükségessé. Míg a topográfiai térképek a földfelszínt általános tájékozódási céllal, nagy részletességgel, közepes vagy nagy méretarányban ábrázolják (Faragó et al. 2010), addig a tematikus térképek kis méretarányban, gyakran közvetlenül nem érzékelhetố jelenségeket (pl. születések száma) ábrázolnak (Papp-Váry, 2012). Ugyanakkor egyes jelenségeket többféle kartográfiai ábrázolási módszerrel lehet bemutatni. Ennek következtében felmerült a kérdés, hogy melyik ábrázolásmód a legmegfelelőbb? A kartográfiai kommunikációs modellek kifejlôdésének egyik mozgatórugója, hogy a kommunikációelmélet segítségével meg lehessen fejteni a pontos folyamatokat a térképkészító és térképolvasó információcseréje között.

Koláčný 1969-ben mutatta be elméletét, amelyben a térképet mint kommunikációs eszközt ábrázolta. Problémának tartotta, hogy a térképészek elvárták a térképolvasótól, hogy „alkalmazkodjon” a térképeik jelkulcsához. Emellett fontosnak látta a térképolvasók igényeinek, szükségleteinek a figyelembevételét. Szerinte a térképek feladata, hogy a felhasználók a leghatékonyabban tudják azokat használni, megfeleljenek az igényeiknek, könnyen olvashatónak és érthetônek, racionálisnak, emellett vonzónak és esztétikusnak is kell lenniük. Véleménye szerint ezek a szempontok akkor érhetók el, ha a térképész nem csak a célközönség igényeit ismeri, hanem azok térképolvasási képességeit, ismereteit, valamint a térképhasználat körülményeit és módját is. Nem szabad úgy tekinteni a térképkészítésre és térképhasználatra, mint két egymástól elkülönülô folyamatra.

Koláčný továbbá ajánlásokat is tett a kommunikációs modell további vizsgálatára. Megemlítette többek közt különbözó demográfiai csoportok térképi igényeinek a vizsgálatát, a térképolvasók szubjektív tényezóinek vagy a környezeti tényezóknek a hatását a térképolvasás során.

Ratajski (1977) megalkotta a kartológiát, mint tudományágat, amely a korológiai (a térbeli elterjedéssel foglalkozó tudományág) információ kifejezését és átadását tanulmányozza. Ehhez a térképet nevezte meg mint az információátadás eszközét. Három fô részét emelte ki a kartológiának: a térképi megismerést, a kartográfiai módszertant és a kartográfiai információtovábbítás elméletét. Az információtovábbítás modellje megfogalmazza a kapcsolatot a térképész valósága, a térkép és a térképolvasó valósága között. Kiemeli, hogy a térképész által közölni kívánt, és a térképolvasó által befogadott valóság nem teljesen megegyezô, bár van átfedés a kettố között. 
Robinson és Petchenik (1975) nem értettek teljesen egyet a kartográfiai kommunikáció lineáris ábrázolásával. Kifejtették, hogy a kartográfiai kommunikáció során nem csupán adatvesztés történhet, hanem több, a térképszerkesztő által közvetlenül nem ábrázolt információ kinyerése is. Példának hoztak fel egy vízrajzi térképet: ha megfelelô szakember vizsgálja meg a térképet, akkor következtetéseket vonhat le az alapkôzet típusáról, miközben a térképen eredetileg nem szerepelt geológiai tematika. Ilyen esetben, amikor a térképolvasó következtetésekkel új információt tud levonni a térképről, adatnyerésről beszélhetünk. Emellett szót ejtettek a térképkészítő-térképolvasó kommunikációja közti adatvesztésrôl is. Ennek oka lehet a térkép téves értelmezése, hibás feldolgozása vagy akár a helytelen ábrázolásmód is.

Taylor (1991) kifejti, hogy a térképek segítségével széles körben lehet ábrázolni, elemezni, bemutatni és közölni kvantitatív és kvalitatív információkat egyaránt. A kognitív kartográfia az ô véleménye szerint egy sajátos folyamat, mely az emberi elme térbeli kapcsolatokat és mintázatokat felismerô képességével foglalkozik. Véleménye szerint a térképészetben

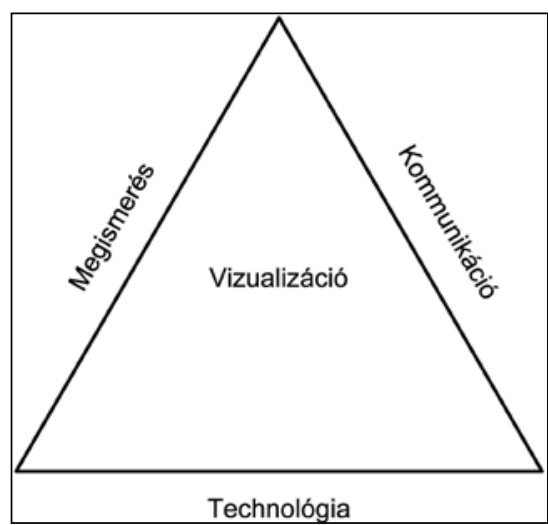

2. ábra. Taylor (1991) kartográfiai vizualizációs háromszöge

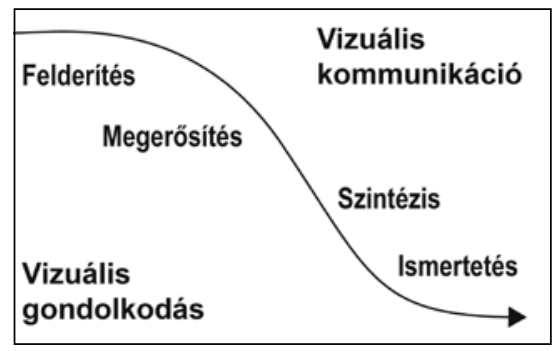

3. ábra. DiBiase „csúszda” modellje (1990). egyforma figyelmet kell fordítani a megismerésre (kogníció), a kommunikációra és a technológiára (2. ábra). Úgy gondolja, a kor térképészetével az a probléma, hogy túl nagy hangsúlyt fektet a technológiára, sok esetben a megismerés és kommunikáció kizárásával.

DiBiase (1990) a térképhasználatot és a térképi kommunikációt egy négylépcsôs „csúszda” modellel mutatta be (3. ábra): (1) felderítés (az információ megismerése több nézôpontból, kutatási kérdések feltevése, hipotézisek felállítása), (2) megerôsítés (a hipotézisek vizsgálata, kutatási kérdések megválaszolása), (3) szintézis (következtetések levonása) és (4) ismertetés (az eredmények széles körú bemutatása). Modelljének a lényege, hogy a tudományos megismerés során a kutatóknak többféle és számosabb térképi ábrázolásra van szükségük, de ahogy értelmezik a problémát és levonják a következtetéseket, a vizuális kommunikáció már kevesebb, de optimalizált megjelenítést igényel.
DiBiase „csúszdája” segítségével az egyes térképtípusok evolúciója is vizsgálhatóvá válik, ha a különbözô korú térképeket beilleszthetjük a modell megfelelő lépcsőfokaiba. Így tett Albert (2019), aki a geológiai térképek elemzését és időbeli változásait vizsgálta. Munkájában bemutatta, hogy a digitalizálódás hogyan juttatta el ezeket a szaktérképeket a nagyobb közönséghez, ami következtében a térképen átadott információ is változni kezdett a különbözô felhasználási módok függvényében.

MacEachren és Kraak (1997) DiBiase modelljét továbbfejlesztve megalkották a kartográfiakockát (4. ábra), amely három tengely mentén mutatja be a térképhasználatot: személyes vagy publikus térképhasználat; ismert vagy eddig ismeretlen tudás prezentálása; csekély vagy nagy térképi interakció. A kartográfiakocka e tengelyekkel kibóvíti a „csúszda” modellt, és megmutatja azokat a magas szintú térképhasználati folyamatokat, amelyeket a vizuális gondolkodás igényel.

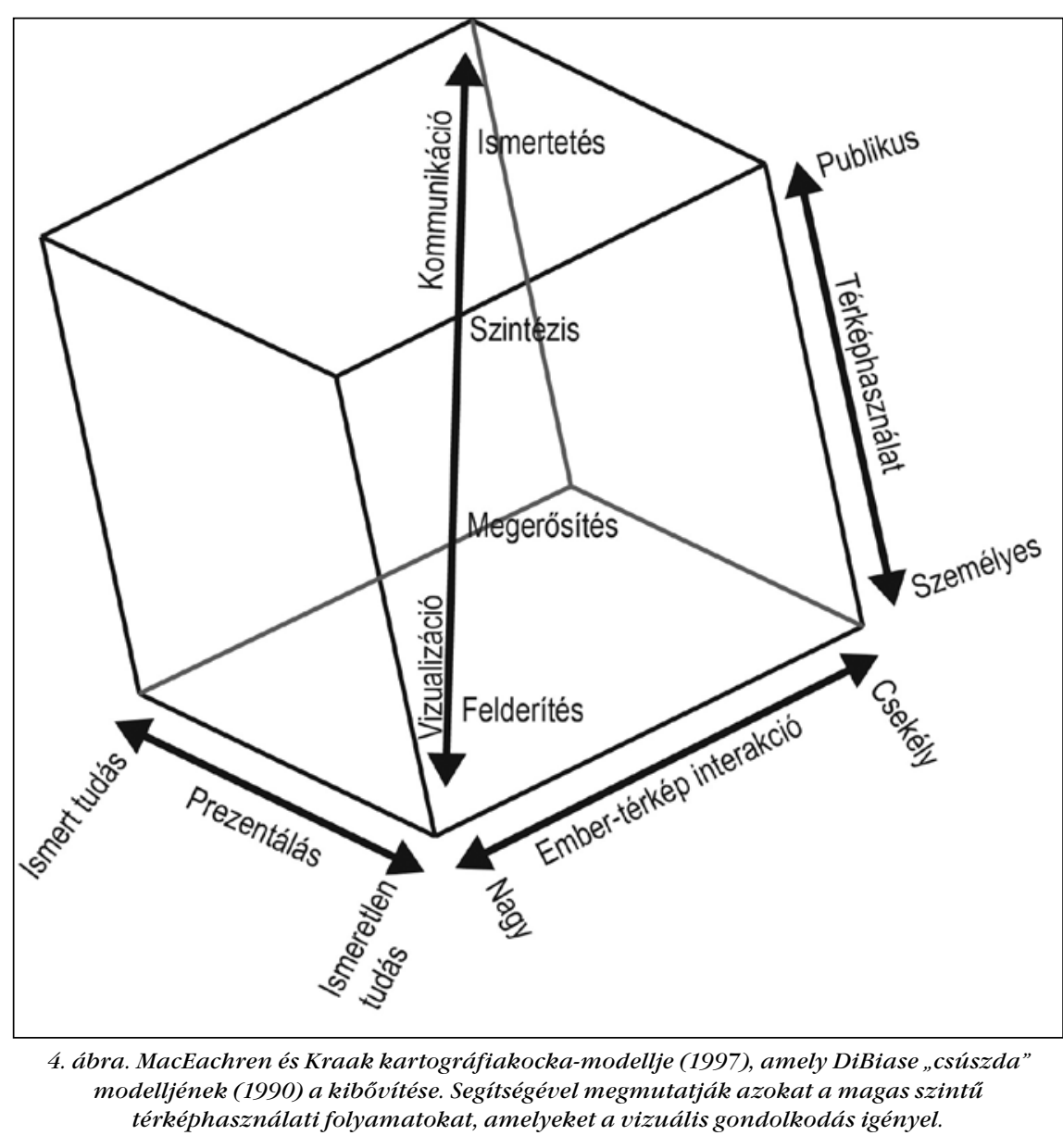


Azaz amíg a felderítés egy személyes, sok ismeretlen tudást átadó térképhasználati folyamat, ami nagy térképi interakciót vár el, az ismertetés egy publikus, meglévố ismereteket átadó, kis térképi interakcióval járó múvelet.

\section{A térképolvasás kognitív megközelítése}

A kognitív térkép a definíció szerint "földrajzi helyszínek tanult belsố reprezentációi” (Lloyd 2000). Ebból adódóan, a kognitív térképek meghatározó tényezôi egyrészt a memóriánkban tárolt korábbi ismeretek. Lobben (2004) kétféle módját említette a kognitív térkép fejlesztésének:

1. A környezeti kognícióról abban az esetben beszélünk, ha a környezetbôl közvetlenül hozzuk létre a kognitív térképünket. Ilyenkor a környezetból tanulunk meg bizonyos mintázatokat, tájékozódási pontokat, amelyek fejlesztik a kognitív térképünket. Ez nincs közvetlen hatással a térképolvasási képességre. Ugyanakkor hatással van a navigációs és útvonaltervezési képességekre, amelyek közvetett módon a térképen való tájékozódást is befolyásolják. Ezen képesség fejlesztésével az iránymeghatározásunk és saját helyzetünk meghatározása is pontosabbá válik.

2. A felmérési kogníció során a kognitív térkép egy létezô térkép tanulmányozásával jön létre. Ez a módszer általában kiegészítóje a környezeti kogníciónak. A legtöbb esetben a térképhasználat megelőzi, vagy párhuzamosan történik a környezeti kognícióval.

Lobben (2004) emellett felsorolt több, a térképolvasáshoz szükséges kognitív képességet is. Az elsố ilyen képesség a mentális forgatás. A kutatások kimutatták, hogy a térképolvasás több idóbe telik, ha a térképolvasónak fejben tájolnia (mentálisan forgatnia) kell a térképet (ShepardHurwitz 1984, Levine et al. 1984). Ugyanakkor a mentális forgatás hatékonyságát befolyásolja a térkép összetettsége. Minél komplexebb egy térkép, annál nehezebbé válik annak mentális forgatása (Steinke-Lloyd 1983). További nehézséget okozhat a térképolvasóknak a térkép tájolása. Mivel a kartográfiai hagyomány szerint a térkép „teteje” az északi irány felé mutat (nagy méretarányú térképek esetében), a más irányba tájolt térképek megzavarhatják a térképolvasókat (Lloyd-Cammack 1995). Ugyanakkor az északi irány feltüntetése nagyobb biztonságot ad a tér képolvasóknak az irány meghatározásában (Szigeti 2016). A mentális forgatás jelentôsége terepi tájékozódáskor tapasztalható. Ilyenkor a térképolvasónak gyakran kell úgy forgatni a térképét, hogy ne észak felé mutasson. Ebben az esetben, akár fejben történik a múvelet, akár konkrét forgatással, a térkép egyéb objektumai számára (pl. pontszerú jelek, megírások) szükséges a mentális forgatás alkalmazása. Ugyanakkor modern, digitális térképek esetében megoldható a térképi elemek forgatása a képernyôn, és ez a probléma kiküszöbölhetô.

A következô kognitív képesség a jelfelismerés. Ez a képesség szükségessé teszi a jelek egymástól való elkülönítését és valós, háromdimenziós objektumokkal való megfeleltetését (Lobben 2004). Ezt a képességet negatívan befolyásolja a térkép összetettsége, ugyanakkor a jelek valós elemekkel történô megfeleltetése is személyenként eltérő hatékonysággal történhet (Winn 1991).

A további képességek, amelyeket Lobben (2004) felsorol, a terepi tájékozódáshoz kötôdnek. Az egyik ilyen képesség a képformálás. Abban az esetben, ha ismeretlen helyen térképpel tájékozódunk, a felmérési kogníció segítségével rendelkezhetünk a terület egy mentális felülnézeti ábrázolásával. Képformálás során ezt a kétdimenziós képet háromdimenzióssá alakítjuk, és mentálisan „látjuk” a terület jellemzóit. A képformálás a tájékozódás közben egy folytonos feladat, azaz a terepi tájékozódás közben folyamatosan használjuk.

A következó képesség a saját helyzetünk meghatározása. Ehhez a térképolvasók valós környezeti elemeket feleltetnek meg a térképi objektumokkal, így elhelyezve magukat a térképen, azaz a képformálással ellentétes múvelet. További különbség Lobben (2004) szerint, hogy ez egy diszkrét feladat, amely a tájékozódás megkezdése előtt történik.

Végül, az utolsó képesség amelyet Lobben (2004) kiemel, az az útvonalkövetés. Ez a képesség tájékozódás közben az iránymeghatározást és a helyzetmeghatározást segíti, és kiegészíti a kognitív térképet a megtett út irányultságával. Ennek segítségével a tájékozódás során meg lehet becsülni a relatív elhelyezkedésünket a kiindulóponthoz képest. Ugyanakkor, a környezeti kognícióval szemben, ez a képesség nem alkalmas a tájékozódásra, azaz nem találunk vele vissza az útvonal egy korábbi szakaszára. Amíg a környezeti kogníció segítségével a környezetünkrôl egy tájékozódásra alkalmas kognitív térképet alakítunk ki, addig az útvonalkövetés segítségével a kiindulóponthoz képesti irányultságunkat tudjuk megbecsülni.

Muir (1985) szerint a térképi jelek ismerete, az irányok, a koordináták és a méretarány meghatározása, valamint a morfológia értelmezésének készsége fejezi ki a térképolvasási képességet. Clarke (2003) ezzel szemben több absztrakt készség alapján határozza meg a térképolvasási képességet. Ezek közé tartozik a felismerés, a mentális forgatás, az emlékezés, a becslés, a következtetés, a jelmeghatározás, az összehasonlítás és a jellemzés stb.

Ezen képességek felhasználásával (Albert et al. 2016) az Eötvös Loránd Tudományegyetem Kísérleti Térképészeti Kutatócsoportjában (KTK) hét kompetenciát határoztunk meg (5. ábra), amelyek mérése segítséget nyújthat a tájékozódásra alkalmas (tehát nagy és közepes méretarányú) térképolvasási képességek számszerúsítésében. A nemzetközi kutatásunkban egyetemi hallgatók segítségével próbáltuk számszerúsíteni a térképolvasási képességet. Online, interaktív térképolvasási tesztekkel vizsgáltuk, hogy miként függ össze a hét kompetencia a térképolvasási képességgel. 


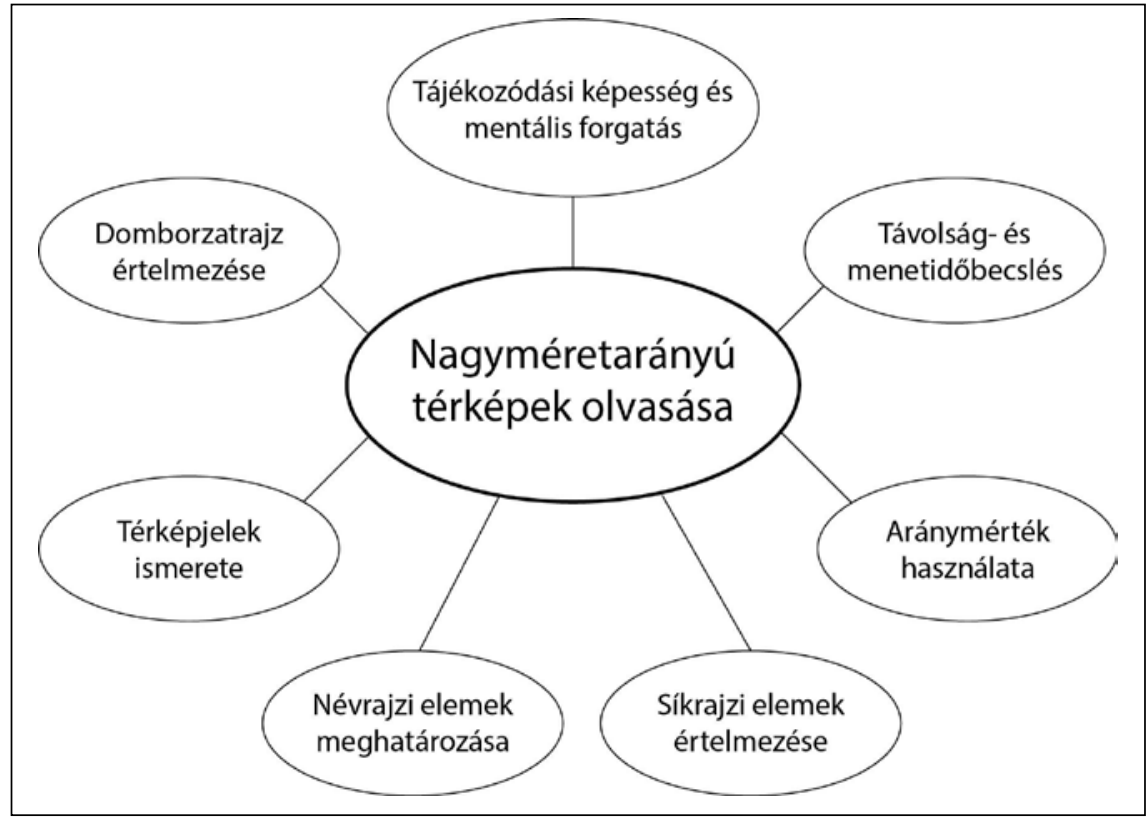

5. ábra. Albert és társai (2016) által meghatározott térképolvasási képességek

A kutatás eredményeit felhasználva 2017-ben megterveztünk egy „személyre szabott" jelkulcsú térképet, amelynek a célja a kartográfiai kommunikáció hatékonyabbá tétele volt az eltérô képességú térképolvasók számára (Albert et al. 2017). Habár ezt a célt csak részlegesen sikerült elérni, a jövőbeli kutatások nagy hasznát vehetik a gyújtött adatoknak, a módszertannak, valamint az eredményeknek. Kiemelendô, hogy a kutatáshoz felhasznált online térképhez kizárólag ingyenes, open source eszközöket és adatokat használtunk (Szigeti et al. 2017).

A Kísérleti Térképészeti Kutatócsoporttal 2019-ben megvizsgáltuk a domborzatrajzi-értelmezési képességet, hogy pontosítsuk ennek a kompetenciának a mérhetőségét (Szigeti et al. 2019). A 195 résztvevôból álló online kutatásban több, a domborzatrajz értelmezéséhez szükséges képességet vizsgáltunk (pl. relatív magasság meghatározása, felszínformák értelmezése, lejtésirány meghatározása stb.). A kutatás eredményéből kiderült, hogy a mentális forgatást és a relatív magasság meghatározását vizsgáló feladatok a legalkalmasabbak a térképolvasási képesség vizsgálatára.

\section{A kognitívterhelés-elmélet kartográfiai alkalmazása}

A kognitív terhelés elméletérôl és a földrajzi információk kognitív terhelésérôl Bunch és Lloyd 2006 ban írt egy részletes értekezést. Megfogalmazásuk szerint a kognitív terhelés azt a munkát jelenti, amely valamilyen információ megszerzéséhez és feldolgozásához szükséges. Ha egy térképi feladatnak magas a kognitív terhelése, akkor azt a feladatot nehéz és sok idôbe telik megoldani, ami a tanulás hatékonyságát csökkenti. Ellenkezố esetben, ha egy térképi feladatnak alacsony a kognitív terhelése, akkor a megoldása könynyú, és kevesebb idôt vesz igénybe. Ugyanakkor figyelembe kell venni, hogy az utóbbi esetben nincs kihívás a tanulásban, így kevés az ösztönzô tényezô.

A kognitívterhelés-elmélet a memóriát két részre osztja: a hosszú távú memóriára és a munkamemóriára (Ooms et al. 2012, Sweller 1988, 1994). Új információ feldolgozásához a munkamemóriát használjuk. Ez nem képes nagyobb mennyiségú információt tárolni, és az ismeretek hosszú ideig tartó tárolására sem alkalmas, erre a hosszú távú memória szolgál. Új ismeret tanulásakor a munkamemóriában lévố friss információ hozzákapcsolódik a hosszú távú memóriában tárolt egyéb ismeretekhez. Amikor szükséges, a hosszú távú memóriából újra elô lehet hívni az ott tárolt információkat. Ezeket az információkat sémáknak nevezik. Kognitív terhelés abban az esetben lép fel, ha egy feladat megoldásakor nem tudunk a hosszú távú memóriából korábbi sémát elôhívni. Ha egy ilyen séma automatikusan elóhívható, és képes tudat alatt múködni, azzal tovább csökken a munkamemória kognitív terhelése.

A kognitívterhelés-elmélet háromféle terheléstípust ír le, amely a munkamemóriát és a tanulási folyamatot befolyásolja:

- A belsố kognitív terhelés a vizuális információ összetettségéből ered. Abban az esetben lép fel, ha túl sok ismeretanyag van jelen a tanulási folyamat során. Túl komplex információt nehéz feldolgozni, ami magasabb kognitív terhelést eredményez. A hosszú távú memóriában tárolt sémákkal csökkenteni lehet ezt a fajta terhelést, azaz a térképolvasás során jelentôs segítséget nyújtanak az elóismeretek. Bunch és Lloyd példának hozza fel a tematikus térképeket: egy olyan személy, akinek vannak az ábrázolt területról előismeretei, könynyebben tudja értelmezni az ábrázolt információkat. Nincs szüksége például a névrajzra, amely számára csak grafikai terhelést jelentene a térképen.

- A külsô kognitív terhelést a zavaró tényezôk vagy az információ rossz ábrázolásmódja okozza. Ilyen terhelést okozhat térképolvasáskor a feladat helytelen megfogalmazása, amely a térképolvasót felesleges múveletek elvégzésére készteti. Megoldást jelenthet olyan figyelemvezetô ábrázolásmód, amely a térképolvasó figyelmét a feladat megoldására fókuszálja.

- Az összekapcsolt kognitív terhelés elôsegítheti a tanulást: új ismeret szerzésekor a munkamemória egy része összekapcsolja az aktív (éppen használt) információt a hoszszú távú memóriában tárolt korábbi ismeretekkel. Ennek segítségével sémákat építhetünk fel a hosszú távú memóriában.

A tanulás folyamata akkor lehet hatékony, ha a kognitív terhelés nem foglalja le a teljes munkamemóriát. A kognitív terhelés csökkentése többféle módon oldható meg. Térképek esetén a külsô kognitív terhelés 
csökkenthetô, ha a térképolvasó figyelmét a közölni kívánt információ felé tereljük. Emellett ki kell zárni minden olyan információt, amely az ismeret átadása szempontjából nem releváns. Ez a módszer akkor lehetséges, ha a térképész pontosan ismeri a térképolvasó képességeit. Ahogy Bunch és Lloyd kifejti, korábban nem lehetett volna gazdaságosan nyomtatni „személyre szabott” jelkulcsú térképeket, ugyanakkor manapság a képernyőn megjelenô térképek jelkulcsa egyszerúen módosítható.

A kezdô térképolvasók a lehetô legegyszerúbb térképeket igénylik a kognitív terhelés csökkentésére. Viszont ahogy nó a tapasztalatuk, az egyszerú térképek nem segítik elô a tanulásukat. Ezt a jelenséget Bunch és Lloyd inverz tapasztalati hatásnak nevezi. Ennek az az oka, hogy amíg a tapasztalt térképolvasók a munkamemóriájukat kizárólag az információ feldolgozására használják, addig a kezdôk ezzel párhuzamosan tanulják az információ feldolgozását (Matlin, 2002), aminek következtében fejlôdnek. Figyelembe kell venni a belsố kognitív terhelést térképtervezéskor: egy túl összetett térkép magasabb kognitív terhelést okoz, mint egy egyszerúen kialakított. Érdemes törekedni a térképek tervezésekor a belsô kognitív terhelés csökkentésére. Ennek segítségével növelhetjük az összekapcsolt kognitív terhelést, amely a tanulási folyamatot segítheti elô.

\section{Összefoglalás}

A kognitív kartográfia kialakulásában nem csupán a térképészet, de a pszichológia és a múvészet fejlődése is jelentôs szerepet játszott. A XX. században a térképi ábrázolás hatékonyságát vizsgáló kutatások egyre gyakrabban érintették a térképi ismeretátadás folyamatát. A '60-as évek végétôl kezdve a kutatók elkezdték felépíteni a kartográfiai kommunikáció modelljét, amelynek alapja az információt közlő és befogadó személy, valamint a köztük lévố médium: a térkép.

A '80-as évektôl a kognitív kartográfiai kutatások elkezdtek háttérbe szorulni, ehelyett a számítógépes kartográfia és a térinformatika került fókuszba. Az elmúlt évek során a térképészet digitalizálódása újra elôtérbe hozta a kognitív kartográfiát: a képernyốn vagy a világhálón történô megjelenítésnek köszönhetôen a tesztek előkészítése, az adatgyűjtés és az adatfeldolgozás egyszerúbbé és gyorsabbá vált, ez pedig új lökést adott a kutatásoknak. Ezen kutatások közül számos a kognitív terhelés elmélet kartográfiai vonatkozásával foglalkozik, vizsgálatuk középpontjában a térképolvasást befolyásoló tényezők állnak.

\section{Köszönetnyilvánítás}

Szeretném köszönetemet kifejezni kollégáimnak a Kísérleti Térképészeti Kutatócsoportban, mivel közös munkánk adta alapját ennek a tanulmánynak. Külön köszönetet érdemel témavezetôm Albert Gáspár, aki szakmailag támogatta e cikk megjelenését.

\section{Irodalomjegyzék}

Albert, G. 2019. The changing use-cases of medium and large-scale geological maps in Hungary. Proceedings of the ICA, 2. évf. július pp. 1-8.

DOI: $10.5194 /$ ica-proc-2-4-2019

Albert, G. - Ilyés, V. - Kis, D. - Szigeti, Cs - Várkonyi, D. 2016. Testing The Map Reading Skills of University Students. In 6th International Conference on Cartography and GIS június pp. 188199. Bandrova, T. - Konečný, M. (eds.), Bulgarian Cartographic Association.

Albert, G. - Ilyés, V. - Szigeti, Cs. - Kis, D. Várkonyi, D. 2017. How hard is it to design maps for beginners, intermediates and experts? Lecture Notes in Geoinformation and Cartography, október, pp. 239-253. DOI: $10.1007 / 978-3-319-57336-617$

Bérces Ádám - dr. Török Zsolt Gyôző 2014 Tér-idôvonatkozású adatok vizualizációs lehetôségei szemmozgáskövetési kísérletek adatainak példáján. In. Balázs B. (szerk.) Az elmélet és a gyakorlat találkozása a térinformatikában V. Térinformatikai konferencia és szakkiállítás pp. 51-59, Debreceni Egyetemi Kiadó.

Bianchini, F. - Palermo, L. - Piccardi, L. Incoccia, C. - Nemmi, F. - Sabatini, U. Guariglia, C. 2014. Where Am I? A new case of developmental topographical disorientation.Journal of Neuropsychology 8. évf. 1. sz. pp. 107-124. DOI: $10.1111 /$ inp. 12007

Board, C. 1978. Map Reading Tasks Appropriate in Experimental Studies in Cartographic Communication. Cartographica, 15. évf. 1. sz. pp. 1-12 DOI: $10.3138 / \mathrm{AG} 15-\mathrm{V} 252-3726-\mathrm{W} 346$
Board, C. 1981. Cartographic Communication. Cartographica, 18. évf. 2. sz. pp. 42-78. DOI: 10.3138/8R07-2125-L843-0767

Bunch, R. L. - Lloyd, R. 2006. The Cognitive Load of Geographic Information. The Professional Geographer, 58. sz. pp. 209-220.

DOI: $10.1111 / \mathrm{i} .1467-9272.2006 .00527 . x$

Chang, K. 1977. Visual estimation of graduated circles. The Canadian Cartographer, 14. évf. pp. 130-138.

Clarke, D. 2003. Are You Functionally Map Literate? Proceedings of the 21st International Cartographic Conference, pp. 713-719.

Crawford, P. V. 1971. Perception of graytone symbols. Annals of the Association of American Geographers, 61. évf. pp. 721-735.

Croxton, F. E. 1932. Graphic Comparison by Bars, Squares, Circles and Cubes.Journal of the American Statistical Association, 27. évf. 177. sz. pp. 54-60.

DiBiase, D. 1990. Visualization in the earth sciences. Earth and Mineral Sciences, 59. évf. 2. sz. pp. 13-18.

Donnon, T. - DesCốteaux, J. G. - Violato, C. 2005. Impact of cognitive imaging and sex differences on the development of laparoscopic suturing skills. Canadian Journal of Surgery, 48. évf. 5. sz. pp. 387-393.

Eells, W. C. 1926. The Relative Merits of Circles and Bars for Representing Component Parts. Journal of the American Statistical Association, 21. évf. 154. sz. pp. 119-132.

Eley, M. G. 1987. Colour-layering and the performance of the topographic map user Ergonomics, 30. évf. 4. sz. pp. 655-663.

Eley, M. G. 1992. Component Processing Skills in the Interpretation of Topographic Maps. Cartographica, 29(1), pp. 35-51. DOI: $10.3138 / \mathrm{I} 543-454 \mathrm{~T}-5477-4832$

Faragó Imre - Gercsák Gábor - Horváth Ildikó - Klinghammer István - Kovács Béla - Pápay Gyula - Szekerka József 2010. Térképészet és geoinformatika I. Klinghammer István (szerk.). Eötvös Kiadó, Budapest

Flannery, J. J. 1971. The Relative Effectiveness of Some Common Graduated Point Symbols in the Presentation of Quantitative Data Cartographica, 8. évf. 2. sz. pp. 96-109. DOI: $10.3138 / \mathrm{J} 647-1776-745 \mathrm{H}-3667$

Freitag, U. 1971. Semiotik und Kartographie: Über die Anwendung Kybernetischer Disziplinen in der theoretischen Kartographie. Kartographische Nachrichten, 21. sz. 5. évf. pp. 171-181.

Gerber, R. V. 1981. Competence and Performance in Cartographic Language. The Cartographic Journal, 18. évf. 2. sz. pp. 104-111. DOI: $10.1177 / 0033688210372953$

Gilhooly, K. J. - Wood, M. - Kinnear, P. R. Green, C. 1988. Skill in map reading and memory for maps. The Quarterly Journal of Experimental Psychology Section A. Human Experimental Psychology, 40. évf. október, pp. 87-107. DOI: $\underline{10.1080 / 14640748808402284}$ Gulliver, F. P. 1908. Orientation of Maps. Bulletin of the American Geographical Society, 40. évf. 9. sz. pp. 538-542. DOI: $\underline{10.1080 / 00221340908986220}$ 
Guzmán, J. F - Pablos, A. M. - Pablos, C. 2008 Perceptive-Cognitive Skills and Performance in Orienteering. Perceptual and Motor Skills, 107. évf. 1. sz. pp. 159-164

Hake, G. 1973. Kartographie und Kommunikation. Kartographische Nachrichten, 23. évf. 4. sz. pp. 137-148

Hergenhahn, B. R. - Henley, T. B. 2013. An Introduction to the History of Psychology ( 7 th ed.). Cengage Learning.

Hsu, M.-L. - Robinson, A. H. 1970. The Fidelity of Isopleth Maps: An Experimental Study University of Minnesota Press.

Ito K. - Sano Y 2011. Cultural Differences in The Use of Spatial Information in Wayfinding Behavior. Proceedings of the 25th International Cartographic Conference.

Kerkovits, K. - Szigeti, Cs. 2018. Relationships Between The Distortions In Map Projections And The Usability Of Small-Scale Maps. In Proceedings of 7 th International Conference on Cartography and GIS, Bandrova, T.Konečný, M. (eds.) pp. 236-245.

Koláčný, A. 1969. Cartographic Information-a Fundamental Concept and Term in Modern Cartography. The Cartographic Journal, 6. évf. 1. sz. pp. 47-49. DOI: $10.1179 / 000870469787700089$

Lawton, C. A. 1994. Gender differences in wayfinding strategies: Relationship to spatial ability and spatial anxiety. Sex Roles, 30. évf. 11-12. sz. pp. 765-779 DOI: $10.1007 / \mathrm{BF} 01544230$

Levine, M. - Marchon, I. - Hanley, G. 1984. The Placement and Misplacement of You-AreHere Maps. Environment and Behavior, 16. évf. 2. sz. pp. 139-157. DOI: $10.1177 / 0013916584162001$

Lloyd, R. 2000. Self-Organized Cognitive Maps Professional Geographer, 52. évf. 3. sz. pp. 517-531.

Lloyd, R. - Cammack, R. 1995. The Construction of Cognitive Maps. Kluwer Academic Publishers. J. Portugali (ed.) DOI: $10.1007 / 978-0-585-33485-1$

Lobben, A. K. 2004. Tasks, Strategies, and Cognitive Processes Associated With Navigational Map Reading: A Review Perspective. The Professional Geographer, 56. évf. 2. sz. pp. 270-281 DOI: 10.1111/i.0033-0124.2004.05602010.x

Maceachren, A. M. - Kraak, M. J. 1997. Exploratory cartographic visualization advancing the agenda. Computers and Geosciences, 23. évf. 4. sz. pp. 335-343 DOI: 10.1016/S0098-3004(97)00018-6

Matlin, M. W. 2002. Cognition. Wiley \& Sons.

Montello, D. R. 2002. Cognitive Map-Design Research in the Twentieth Century: Theoretical and Empirical Approaches. Cartography and Geographic Information Science, 29. évf. 3. sz. pp. 283-304. DOI: $10.1559 / 152304002782008503$

Montello, D. R. - Lovelace, K. L. - Golledge, R G. - Self, C. M. 1999. Sex-Related Differences and Similarities in Geographic and Environmental Spatial Abilities. Annals of the Association of American Geographers, 89. évf. 3. sz. pp. 515-534 DOI: $10.1111 / 0004-5608.00160$

Muir, S. P. 1985. Understanding and Improving Students' Map Reading Skills. Elementary School Journal, 86. évf. 2. sz. pp. 206-216.

Olson, J. M. 1975. Experience and the Improvement of Cartographic Communication. The Cartographic Journal, 12. évf. 2. sz. pp. 94-108.
Ooms, K. - De Maeyer, P. - Fack, V. 2013. Study of the attentive behavior of novice and expert map users using eye tracking. Cartography and Geographic Information Science, 41. évf. 1. sz. pp. 37-54. DOI: $10.1080 / 15230406.2013 .860255$

Ooms, K. - De Maeyer, P. - Fack, V. - Assche, E. Van - Witlox, F. 2012. Interpreting maps through the eyes of expert and novice users. International Journal of Geographical Information Science, 26. évf. 10. sz. pp. 1773-1788.

DOI: $10.1080 / 13658816.2011 .642801$

Pápay Gyula - Klinghammer István - Török Zsolt Gyôzô 1995. Kartográfiatörténet, Klinghammer István (szerk.) Eötvös Kiadó, Budapest

Papp-Váry Árpád 2012. Az elméleti térképészet irányzatai. Földrajzi Közlemények, 136. évf. 1. sz. pp. 66-76.

Petchenik, B. B. 1977. Cognition in Cartography. Cartographica, 14. évf. 1. sz. pp. 117-128 DOI: 10.3138/97R4-84N4-4226-0P24

Pôdör Andrea 2002. A halak tartózkodási helyének horgásztérképeken történô legoptimálisabb ábrázolásának vizsgálata (Examination of the optimal representation of the residence of fishes on maps). Studia Cartologica, 12. évf. pp. 153-160.

Ratajski, L. 1977. The Research Structure of Theoretical Cartography. Cartographica: The International Journal for Geographic Information and Geovisualization, 14 évf. 1. sz. pp. 46-57. DOI: 10.3138/P2Q9-616W-0444-0Q34

Robinson, A. H. 1952. The Look of Maps An Examination of Cartographic Design. University of Wisconsin Press

Robinson, A. H. - Petchenik, B. B. 1975. The Map as a Communication System Cartographica, 14. évf. 1. sz. pp. 92-110. DOI: $10.3138 / 0235-6117-1 T W 6-06 T 5$

Shepard, R. N. - Hurwitz, S. 1984 Upward direction, mental rotation, and discrimination of left and right turns in maps. Cognition, 18. évf. 1-3. sz. pp 161-193.

DOI: $10.1016 / 0010-0277(84) 90024-6$

Shortridge, B. G. 1979. Map Reader Discrimination of Lettering Size. The American Cartographer, 6. évf. 1. sz. pp. 13-20.

Slocum, T. A. - Blok, C. - Jiang, B. Koussoulakou, A. - Montello, D. R. Fuhrmann, S. - Hedley, N. R. 2001 Cognitive and Usability Issues in Geovisualization. Cartography and Geographic Information Science, 28. évf. 1. sz. pp. 61-75.

DOI: $10.1559 / 152304001782173998$

Steinke, T. - Lloyd, R. 1983. Images of maps: A rotation experiment. Professional Geographer, 35. évf. 4. sz. pp. 455-461. DOI: $10.1111 / \mathrm{j} .0033-0124.1983 .00455 . \mathrm{x}$

Sweller, J. 1988. Cognitive load during problem solving: Effects on learning Cognitive Science, 12. évf. 2. sz. pp. 257-285.

DOI: 10.1016/0364-0213(88)90023-7

Sweller, J. 1994. Cognitive Load Theory, Learning Difficulty, and Instructional Design. Learning and Instruction, 4 évf. 4. sz. pp. 295-312. http://www. sciencedirect.com/science/article/ pii/0959475294900035 DOI: $10.1016 / 0959-4752(94) 90003-5$
Szigeti, Cs. - Albert, G. - Virág, I. - Dávid, K. - Dávid, V. 2017. On the Way to Create Individualized Cartographic Images for Online Maps Using Free and Open Source Tools. Advances in Cartography and GIScience pp. 131-144. Springer.

Szigeti Csaba 2016. Térképek információtartamának mérése individualizált turistatérképek esetén. In Tavaszi Szél pp. 489502. Keresztes G. (szerk.), Doktoranduszok Országos Szövetsége.

DOI: 10.23715/TSZ.2016.1

Szigeti, Cs. - Albert, G. - Ilyés, V. - Kis, D. Várkonyi, D. 2017. On the way to create individualized cartographic images for online maps using free and open source tools. Lecture Notes in Geoinformation and Cartography, pp. 131-144. DOI: $10.1007 / 978-3-319-57336-610$

Szigeti, Cs. - Albert, G. - Kis, D. 2019. Measuring the map readers interpretation of hypsography. In Proceedings of 7 th International Conference on Cartography and GIS, Bandrova, T.- Konečný, M. (eds.) pp. 547-555.

Taylor, D. R. F. 1991. A conceptual basis for cartography: new directions for the information era. The Cartographic Journal, 28. évf. május, pp. 213-216. DOI: $10.1179 / 000870491787859214$

Taylor, R. M. 1985. Colour Design in Aviation Cartography. Displays, 6. évf. 4. sz. pp. 187-201.

Thrower, N. J. W. 2008. Maps and Civilization: Cartography in Culture and Society. The University of Chicago Press.

Török, Zs. Gy. - Török, Á. - Tölgyesi, B. - Kiss, V. 2018. The virtual tourist: Cognitive strategies and differences in navigation and map use while exploring an maginary city. International Archives of the Photogrammetry, Remote Sensing and Spatial Information Sciences - ISPRS Archives, 42. évf. 4. sz. pp. 703-709.

DOI: 10.5194/isprs-archives-XLII-4-631-2018

Wakabayashi, Y. 2013. Role of Geographic Knowledge and Spatial Abilities in Map Reading Process: Implications for Geospatial Thinking. Geographical Reports of Tokyo Metropolitan University, 48. évf. pp. 37-48.

Winn, W. 1991. Learning from maps and diagrams. Educational Psychology Review, 3. évf. 3. sz. pp. 211-247. DOI: $10.1007 / \mathrm{BF} 01320077$

Zentai, L. 2018. The Transformation of Relief Representation on Topographic Maps in Hungary: From Hachures to Contour Lines. Cartographic Journal, 55. évf. 2. sz. pp. 150-158.

DOI: $\underline{10.1080 / 00087041.2018 .1433475}$

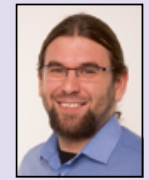

Szigeti-Pap

Csaba

doktorandusz

ELTE Földtudományi Doktori Iskola

ELTE IK Térképtudományi és

Geoinformatikai Intézet

szgtcsaba@gmail.com 